\title{
As derrotas do Sertanejo
}

Hildebrando Campestrini*

O sertanista Joaquim Francisco Lopes realizou quatro viagens exploratórias no sul da província de Mato Grosso, entre 1829 e 1857, cujos relatórios são fonte rica e fiel de informações, principalmente sobre o povoamento do território.

Palavras-chave: Explorações. Joaquim Francisco Lopes. Mato Grosso.

Explorer Joaquim Francisco Lopes carried out four exploratory trips throughout the south of Mato Grosso province, between 1829 and 1857. His reports are rich and faithful source of information, especially about the settlement of the territory.

Key words. Explorations. Joaquim Francisco Lopes. Mato Grosso.

\section{O SERTANEJO}

A Revista do IHGB (ref. 51, p. 95), sob o título Sertanejo, divulgava, em 1888, o seguinte: No dia 8 de maio de 1874, na vila de Jataí, Paraná, segundo escrevem dali, faleceu o cidadão Joaquim Francisco Lopes, na idade de 78 anos. Era casado em terceiras núpcias, deixando viúva e seis filhos de menor idade, sendo a mais moça de dois anos. A sua prole eleva-se a 22 filhos. Joaquim Francisco Lopes foi o sertanejo, que no tempo do finado barão de Antonina abriu, acompanhado do engenheiro João Henrique Elliot, este sertão, e fez a exploração de todo este terreno até Mato Grosso. Prestou, durante a vida, relevantes serviços à pátria. Vivia ultimamente entregue aos seus minguados recur-

\footnotetext{
* Historiador. Presidente do Instituto Histórico e Geográfico de Mato Grosso do Sul. ihgms@ihgms.com.br
}

Albuquerque: revista de História, Campo Grande, MS, v. 1, n. 1, p. 207-226, jan./jun. 2009207 
sos e esquecido de todos, morrendo em extrema pobreza. Nasceu a 7 de setembro de 1805. Era filho de Piumhi em Minas Gerais.

Joaquim Francisco Lopes, o Sertanejo, fez diversas viagens de exploração no sul de Mato Grosso, registrando-as em relatórios, mais conhecidos como bandeiras ou DERRotAs ${ }^{1}$, termo empregado na época para indicar viagens de exploração. Além das excursões aqui relatadas, Lopes realizou outras, principalmente no sertão do Paraná, onde participou da instalação da Colônia Indígena de São Jerônimo, que dirigiu de 1859 até seu passamento, ocorrido, segundo alguns autores, em 1868, sendo nela enterrado.

Joaquim Francisco Lopes pode ser considerado sertanista profissional, não só por dedicar boa parte da vida à atividade, mas também por ter pagas, principalmente pelos cofres públicos, estas empreitadas, deixando, daí, como prestação de contas, os relatórios de seus giros.

Tais relatórios, pela riqueza de informações e credibilidade do autor, tornaram-se fonte indispensável aos que buscam entender a situação do território hoje sul-mato-grossense de 1829 a 1857.

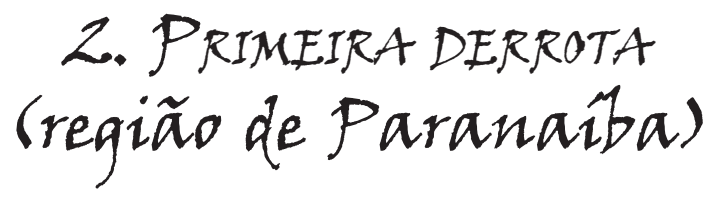

Em 1829 o Sertanejo iniciou a exploração do sertão de Santana, em terras há pouco descobertas pelos irmãos Garcia Leal, moradores do pontal do Triângulo Mineiro. Assim começa o relatório²: 1829. Entrada para o sertão da Paranaíba. Fui convidado pelo sr. Sousa, seguimos em fins de julho, entrei com dois animais e quatro cães veadeiros, alcancemos os senhores Garcias, na Paranaiba, fazendo canoas a nossa espera, pois nos convidou para a dita entrada; descobriu o sertão no ano de 28, perdendo os ditos Garcias dois

\footnotetext{
${ }^{1} \mathrm{O}$ texto das quatro derrotas, atualizado por H. Campestrini, está disponível na biblioteca eletrônica do Instituto Histórico e Geográfico de Mato Grosso do Sul (www.ihgms.com.br).

${ }^{2}$ As citações (no itálico) foram extraídas de A bandeira de Joaquim Francisco Lopes - 1829. Boletim do Departamento do Arquivo do Estado de São Paulo, vol. III, São Paulo, Tip. do Globo, 1943.
} 
anos de entrada sem poderem descobrir; saltamos a dita Paranaíba em lugar largo, e manso mato, serradões e pântanos; saindo nos campos de Santa Ana, apartamo-nos em três bandeiras, a do Sousa constava de onze pessoas, e 24 animais, na qual eu me achei. Entremos por cima a ganhar águas do Sucuriú e voltemos das águas do dito nas cabeceiras denominado Pantano ${ }^{3}$, e fundou-se duas fazendas, uma para Inácio Furtado, e outra para Domingos Rodrigues, por não termos conhecimento do sertão, apatranhemos e voltemos para nossas casas.

No mês de maio de 1830, Joaquim Francisco Lopes entrou nas matas do rio Grande a descobrir campos devolutos, retornando no final de agosto para dirigir-se, no começo de setembro, a Paranaíba, como informa: Segui escoteiro para Paranaíba e cheguei no Monte Alto à casa do sr. capitão José Garcia Leal, o qual há pouco tinha chegado do sertão, e me fez ver boas fazendas que achou, e o sertão que seguia, e demarcou de olho uma fazenda para mim nas margens do rio Paraná, e me ofereceu mantimentos e a sua fazenda para morar, até cultivar a minha. Voltei a casa, cheguei em fins de outubro.

Em 1831, o sertanista decidiu estabelecer-se na região dos Garcias, enfrentando, com muita decisão, toda sorte de dificuldades, comuns a todos os que aí se iam fixando, cujo relato comove:

Aviei-me com o necessário, e mudei-me para o sertão. O que muito me custou, por causa das grandes pestes do carrapato, que me foi preciso comprar milho para os bois, e azeite para untá-los, e pentear com pente fino para extinguir a grande imundicie, e mesmo a peste de urinar sangue as quais aturaram quatro anos, e destroçou as criações de Minas Gerais; advirto que saí em abril da Vila Franca do Imperador e cheguei a 20 de junho ao Monte Alto, na fazenda do sr. capitão José Garcia Leal.

No dia 24 embarquemos no fundo da roça do dito no mencionado rio Grande de Minas, eu, o dito Garcia, com camaradas: Alexandre, Inácio, Antônio e Barbosa, e subimos Paranaíba acima até novo porto que se abriu em um lugar estreito, firme e bom; (a 10 de julho cheguemos no dito porto) com muitos

\footnotetext{
${ }^{3}$ A palavra Pantano sempre foi pronunciada, na região, como paroxítona.
}

Albuquerque: revista de História, Campo Grande, MS, v. 1, n. 1, p. 207-226, jan./jun. 2009209 
couros que se tirou, e também de uma onça que acuou em terra com dezoito cães contra, já atirada, porém pouco ofendida; fiz-lhe fogo no avançar nos cães que mal roçou o chumbo pelo cabelo; fazendo que tinha caido puxei por um facão para defender os cães, a dita cuidou em se meter em um batume mui fechado; lancei a mão na cauda e pelejamos até eu vencê-la; neste tempo chegou o Garcia e ambos acabemos de tirar a vida do inimigo; pelas onze horas do dito dia 10 chegaram os entrantes que nós esperávamos por terra, e todos neste mesmo ano se afazendaram etc. e muito satisfeito ficamos. Advirto que fizemos roça em Santa Ana para se formar a nova situação do dito Garcia.

Voltando para o Monte Alto encontrei meu pai no porto, destinado a fazer canoas e rodar a descobrir rio Verde. Fui acompanhá-lo e levemos três canoas, e quatorze índios caiapós. Chegando na barra da dita com o rio Grande topamos com índios da aldeia do Tietê; pousemos por baixo da ilha Grande; fugiram os ditos quatorze indios e ajuntaram-se com os da aldeia.

Enfim, continuamos a viagem com nove pessoas a saber: eu, meu pai, e três manos, dois escravos, e dois camaradas; subimos pelo ribeirão de Santa Quitéria a ver uma fazenda que o dito Garcia deu a meu pai; fizemos roça e voltemos; rodamos; no Arapungá vi a meu pai, dois irmãos, dois escravos, dois camaradas morto na boca dos canais, por não sabermos do varador, porém, por milagre escaparam da morte, e seguimos; abaixo do Sucuriú no lado direito demos princípio a fazer posses.

Chegando na ilha Comprida, topamos canoas de Francisco Goiano, e chegando no rio Verde, subimos por este, aposseando de um e outro lado três dias e meio; largamos as canoas na boca de um riacho que the demos o nome de Espera, e aí ficou meu mano José, por ter cortado um pé, e um camarada José Gonçalves; eu, meu mano Manuel, e o escravo Vicente, seguimos rio Verde acima pela parte direita, pondo posses, e meu pai, meu mano João, e Francisco Escravo sapateiro, e o camarada Manuel Peão, fazendo posses da parte esquerda, e chegaram até o ribeiro Santa Rita, como consta do livrinho, e voltaram.

Eu cheguei até um riacho de canoa que lhe pus o nome Santa Bárbara (deve ser o atual rio do Pombo); voltei e ajuntemo-nos na Espera e seguimos para casa onde chegamos com felicidade e nos acabou o mantimento; 
nesta jornada comíamos o que encontrávamos; valeu-nos haver muitas frutas de jatobá, e muito mel de abelhas; em todo o decurso da viagem gastamos quatro meses.

Em dezembro passei o meu carro para Santa Ana, carregado de mantimento e plantações para se fundar a nova situação de Santa Ana; passou-se gados e porcos do dito Garcia.

Como se viu, acompanhavam-no nessas andanças o pai (Antônio Francisco Lopes), os irmãos Gabriel (que se casaria com Dona Senhorinha), José (futuro Guia Lopes da Laguna), Manuel, João, Remualdo; e os cunhados Alcino e Antônio Vieira Moço. Em 1832 fixou-se na sua fazenda, Monte Alegre, bem ao sul de Santana do Paranaíba, continuando a percorrer aquela região.

Nos anos de 1832 e 1833 Joaquim Francisco encarou, com resignação e denodo, doenças e morte entre seus familiares:

No ano de 32 fiz uma canoa no Monte Alto, na roça do referido Garcia, fui maleitado que acompanhou-me seis meses; rodei eu, meu mano Gabriel (este ainda desensarado de sezões) e o meu escravo Lourenço. Fiz roças nas margens do rio Paraná, retirado três quartos de légua, e plantamos; meu mano ficou em termos já de morte por recair das ditas sezões; voltei por caminho de terra a Santa Ana com sete dias de viagem e aí ficou meu mano. Eu e o escravo fomos ao Monte Alto em quatro dias etc.

A 10 de novembro aprontei-me com o necessário e mudei-me conduzindo trinta porcos para a roça que eu havia feito e na minha marcha adoeceram quatro filhinhos meus de maleitas, que por este motivo cheguei a 20 de janeiro de 33.

Os meninos tiveram melhoras; em o $1 .^{\circ}$ de fevereiro chegaram na minha morada doze famílias de índios caiapós, destes, um ladino por nome cabo José; justei os ditos para ajudarem-me tirar um rego-d'água, levantar casas no mencionado lugar demarcado de olho pelo dito Garcia; pus o nomeFazenda do Monte Alegre.

Também o ano de 1834 não foi só de alegrias para o sertanista: Em janeiro de 1834, aprontei o carro e quatro bois, e largando porcos, roças e tudo o mais que me era pesado, segui a marcha e chegando em Santa Quitéria fiz

Albuquerque: revista de História, Campo Grande, MS, v. 1, n. 1, p. 207-226, jan./jun. 2009211 
canoa de um pau de mamão-do-mato (que o chamam jacatiá), passei a bagagem ficando o carro, por não poder passar; matei um boi, sequei a carne, deixei a mulher efilhos e a escrava entregues ao tempo e fui buscar socorro (rompendo campos dois dias), cheguei em Santa Ana caminhando dezesseis léguas; encontrei mudado de novo o dito Garcia, o qual me deu um escravo, três bois e um cavalo, para coadjuvar-me; reverti-me para o lugar onde havia deixado as partes de meu corpo; os encontrei da maneira que os havia deixado, sem serem ofendidos de coisa alguma, graças à Divina Providência que nunca desampara seus filhos, etc.

Passei o carro e não podendo seguir por a mulher ter um grande ataque, mandei o preto que se recolhesse a apresentar-se a seu senhor, e passados oito dias continuei a minha marcha indo sempre com muito vagar, e sempre cheguei em Santa Ana com felicidade etc.

Em abril o dito Garcia enviou-me a fazer-lhe fazendas no Sucuriú, que fiz cinco para o dito e duas para dois companheiros; gastei nesta viagem de ida e volta 43 dias; em agosto deste mesmo ano fui à Vila Franca, à casa de meu pai, ver meios para conduzir minha família.

Em setembro aprontei-me de todo o preciso, etc. Comprei seis animais cavalar, a saber: três curitibanos arreados com cangalha, os quais foram de meu mano Manuel, por $90 \$ 000$ rs; um ruço capão do compadre Jacinto, por 42\$000; um poncho, sela, e mais aviamentos 60\$000; um ruço pedrês, de João Rodrigues por 36\$000, e assim mais conduzi alguns cavalos emprestados; pus em roça de milho e abóboras e logo engordaram, e voltei para o Garcia, eu, meu mano Remualdo, meu cunhado Alcino e o escravo Vicente, de meu pai.

Em outubro cheguei no Garcia; em fins do dito outubro fiz um bangüê para o doente e conduzi a minha família para a casa de meu pai, com muita felicidade, a qual viagem conclui em fins de novembro; logo que chegamos adoeceu minha filha Custódia, de maleitas e meu mano Remualdo, de sezões, e meu cunhado Alcino, de maleitas. Advirto mais que para a referida viagem comprei uma égua castanha de meu tio Francisco de Paula, por $40 \$ 000$.

No dia $1 . o$ de julho de 1835, Lopes entrou para o sertão do rio Verde com o mano José e sua família, de mudança para a fazenda do cunhado Vieira. 
E, depois de relacionar os animais que comprou, continua: Cheguei na fazenda do sr. Januário Garcia, o qual senhor supriu-me de farinha e arroz, etc. Segui a minha derrota deixando a meu cunhado na casa do sr. Antônio Barbosa; em 4 de agosto embarquei-me em batelão, no rio da Paranaíba a retificar posses do rio Verde, postas no ano de 1831 e tomar conta de uma fazenda que comprei, constante de papéis que se acham em meu poder, etc.

Em 1836 Lopes iniciou a abertura de uma picada, que, de Santana do Paranaíba, alcançou Miranda, aproveitando o percurso para explorar o alto Sucuriú. Assim inicia seu relato: Eu, Joaquim Francisco Lopes, meu cunhado Antônio Vieira Moço, meu mano Gabriel Francisco Lopes e um escravo do dito meu cunhado, por nome Domingos, e seus animais cargueiros, quatro de sela e dois cachorros, um por nome Violento e outro Nhoembré, no dia segundafeira, a 27 de junho de 1836, saímos da casa do sr. Januário Garcia Leal e pousemos no ribeiro por nome Ariranha, perto de um barreiro, terça, 28, falhemos para picar uma mata de facão, a ver subida na serra para romperem rumo do atalho à estrada de Cuiabá.

Subindo a serra, pousou nas cabeceiras do Santana e alcançou as do Indaiazinho e, daí, as do Indaiá Grande. Seguindo o rumo norte, marcou em uns paus do campo o rumo do sudoeste, para guia do pique da estrada do atalho de Cuiabá (estrada do Piquiri), que, naquele ano, estava alcançando o sertão dos Garcias. Em seguida procurou o rio Jauru, de onde escreveu para as autoridades do povoado do Piquiri, dando-lhes parte dos seus giros. Saindo do sertão dos Garcias e depois de atravessar o rio Aquidauana, chegou a Miranda, cujo presídio (comandado por João José Gomes) assim descreve: $2{ }^{a}-29$ (de agosto de 1836), cheguemos e fizemos ver aos de Miranda as nossas investigações; advirto que o dito Forte tem quatro frentes de casas, duas arruadas, cercas de taquaruçus e as outras só a frente. O forte, no meio, cercado de madeira em pé, apontadas de quatro quinas, aterrado alto por dentro, e tem sentinela viva de dia e de noite; tem os índios aldeados ao pé do Forte com suas lavouras, engenho de bois e fazem rapaduras e melado e fabricam a farinha de mandioca; as nações são estas: Guaicurus, Guanás, Guaxis (estes são aliados), há outras nações que existem retiradas assim como Ipagmas, Caiubás e outras mais, etc.

Albuquerque: revista de História, Campo Grande, MS, v. 1, n. 1, p. 207-226, jan./jun. 2009213 
Daí retornou a Camapuã e, no dia 5 de dezembro, voltou (devolvi-me para Miranda). Ao final desta parte, depois de descer a serra de Maracaju pelas águas que deságuam no Paraguai, escreve: Advirto mais nas vargens de paratudais, que nós chamamos cruílas, ou nos carandazais muito sal da terra trigueiro, e alvo, e muito salitre se pode formar grandes fazendas de criar, e se formar grande terra, imediato os matos baixos dá bem mantimentos, até mesmo nas tabocas. Nos campos me parece dar trigos; enfim, podese contar este sertão por patrimônio do Brasil.

Em fevereiro de 1837, seguiu embarcado, de Miranda, para Cuiabá, para apresentar ao presidente da província as entradas de sertão e mapas de rios e comunidades de estradas para São Paulo e Minas Gerais. Subindo o rio Paraguai, passou pelo morro do Rabicho, pelo de Ladário (que defronta com o morro da Conceição e a povoação de Corumbá de Albuquerque), pernoitando nesta povoação, cujos habitantes não podiam criar criações algumas por muitos morcegos. Continuando passou pela baía de nome Chaneca, pela povoação dos Dourados, encontrou índios guatós, passou pelo morro do Caracará. Mais adiante, fez almoço num bananal, dentro de um capão plantado pelos antigos paulistas. Dias depois, pousou num aterrado que fizeram os antigos paulistas e plantaram um grande bananal. Após passar pelo morro de Melgaço e pela capela de Santo Antônio, chegou, no dia 20 de março, a Cuiabá.

$\mathrm{Na}$ volta, entrou no rio São Lourenço e, pelo seu afluente Piquiri (em verdade o Itiquira), chegou ao Destacamento do Piquiri no dia 3 de maio, quando se apresentou ao comandante daquele quartel, cabo José Gonçalves. Daí, tomando a estrada do Piquiri, dirigiu-se a Santana do Paranaíba, aí chegando nos primeiros dias de junho.

Encarregado, pelo presidente de Mato Grosso, de transpor o rio Paraná no lugar que julgasse mais conveniente, começando uma picada por onde pudesse passar um cargueiro, até a vila de Piracicaba, Lopes, em Junho daquele ano, dirigiu-se ao porto São José, na barra da Água Limpa, no Paraná, na fazenda de seu pai.

A seguir, locou, na barra do córrego Água Limpa, um porto (tudo indica que seja o atual Tabuado), bem descampado de um e outro lado; muito bom porto, pouco corre até o meio - parte é parado, a razão de ter uma praia de pedras 
que vem ao meio do rio por cima do porto; e iniciou a picada, concluída em dezembro do ano seguinte, trabalho que lhe valeu duzentos mil réis em moeda e cem cabeças de gado, pagos pelo governo.

\section{SEGUNDA DERROTA \\ (Paraná - Baixo Paraguai)}

Pretendia o barão de Antonina encontrar um caminho que, partindo do Paraná, chegasse ao baixo Paraguai, porque a viagem fluvial de Porto Feliz para Cuiabá já era impraticável. Para tanto foi formada uma bandeira, chefiada por Joaquim Francisco Lopes e relatada por João Henrique Elliott.

Depois de algumas entradas para conhecer melhor as terras paranaenses, embarcava no Tibagi a sexta expedição ${ }^{4}$, destinada à província de Mato Grosso, jogando a vida em uma empresa desaprovada por todos. No dia 11 de agosto estavam os expedicionários no rio Paraná, depois de navegar pelo Paranapanema. Duas léguas abaixo da ilha da Meia Lua (na foz deste rio), encontraram um córrego, que imaginavam ser o Samambaia. Subindo-o, pouco navegaram, por ser estreito e rápida a corrente. Desembarcaram para procurar o caminho que da freguesia de Santana do Paranaíba ia para a Vacaria. Aí encontraram várias malocas de caiuás. No dia 19, seis léguas depois, deram com um trilho que seguia a rumo de oeste, passando sempre pelo coxilhão que reparte as águas do Anhanduí $e$ as do rio de São Bento.

Depois de andarem naquele trilho dezoito léguas, chegaram à fazenda de Francisco Gonçalves Barbosa; três léguas adiante, no dia 26, à de Antônio Gonçalves Barbosa (a Boa Vista), duas léguas após atravessar o rio Vacaria. Depois de apontar que o fazendeiro foi o primeiro morador da região da Vacaria e estava ali há seis anos, o relatório informa que os Barbosas encontraram naquela região mais de duzentas cabeças de gado vacum bravio, desse que deixaram os espanhóis no ano de 1648 quando abandonaram tais lugares.

${ }^{4} \mathrm{O}$ itinerário desta exploração foi publicado na Revista do Instituto Histórico e Geográfico Brasileiro, 1848, vol. 10, p. 153-177. Daí se extraíram as citações desta parte.

Albuquerque: revista de História, Campo Grande, MS, v. 1, n. 1, p. 207-226, jan./jun. 2009215 
No dia 30, bem montados, Lopes, Elliot e um camarada seguiram para Miranda. Vinte e quatro léguas adiante, num percurso com poucos moradores, ultrapassaram a serra de Maracaju, quando deram com o clima muito mais cálido, os campos cobertos, chão arenoso, e pouca água, mas excelente pastagem por toda a parte. Nove ou dez léguas adiante (na confluência dos rios Nioaque e Miranda), atingiram a fazenda da Forquilha, do major João José Gomes, que estava em Albuquerque. No dia 6 de setembro entravam em Miranda, cujo presídio estava cercado por uma estacada já bastante deteriorada, com uma pequena guarnição de tropa regular. Observando que muitas casas da povoação estavam abandonadas, relataram: parece que este lugar está em decadência.

No dia seguinte, partiram a pé para Albuquerque. Na fazenda São João da Barra, continuaram em canoa, chegando ao destino no dia 12, quando foram bem recebidos pelo major João José Gomes. Naqueles dias chegaram índios guaicurus cadiueus e no dia 15 Lopes e Elliot visitaram a aldeia dos guanás e de outras tribos.

Voltaram, por terra, para Miranda, distante vinte e quatro léguas, aí chegando no dia 26, quando Lopes visitou algumas aldeias. No dia 29 saíram de Miranda para, no dia 5 de outubro, chegar à fazenda de Antônio Gonçalves Barbosa. No dia 18 embarcaram no rio Vacaria perto da fazenda de Francisco Gonçalves Barbosa, que, com mais quatro pessoas, se reuniria, mais adiante, à comitiva. No dia 20 entraram no Ivinhema, descrito mais adiante, observando que era possível subir canoas francamente pelo rio Santa Maria até um lugar onde, com cinco léguas de varação pelo campo, se podia alcançar o rio Miranda, o que contudo precisava ser examinado com individuação para bem marcar-se o varadouro.

No dia 23, oito léguas abaixo da barra do Vacaria com o Ivinhema, encontraram uns cinqüenta caiuás, que Lopes abraçou e brindou com mantimentos, muitos anzóis, facas, e algumas roupas. No dia 31 entravam nas águas do Paranapanema, no dia 10 de novembro no Tibagi, e no dia 11 chegaram à barra do ribeirão das Congonhas, escolhido para ponto de embarque do comércio da vila de Antonina com Cuiabá, tendo gasto dezoito dias de marcha desde os campos da Vacaria até ali. No dia 27 de dezembro (de 1847) chegavam à fazenda de Perituva, final da empreitada, com seis meses e treze dias de viagem. 


\section{TERCEIRA DERROTA \\ (Paraná - Miranda-Vacaria)}

Cumprindo ordens do barão de Antonina, a comitiva ${ }^{5}$ de Lopes embarcava, no dia 27 de outubro de 1848, no ribeirão das Congonhas. Compunha-se de nove pessoas e de um intérprete, mais Francisco Gonçalves Barbosa, Paulo Rodrigues Soares e José Maria de Miranda, moradores da província de Mato Grosso, que (como se viu) tinham acompanhado Lopes na volta da expedição anterior, e mais o negociante Antônio Felipe com seus camaradas ou homens de comitiva, perfazendo ao todo dezenove pessoas embarcadas em quatro canoas.

Depois de alguns dias de viagem alcançou a comitiva o rio Paranapanema, acampando na foz do Pirapó, onde Lopes se demoraria para algumas explorações, o que fez com que Francisco Gonçalves Barbosa e os dois companheiros prosseguissem nesse mesmo dia a sua viagem, mostrando-se bastante desejosos de chegarem a suas moradas, que distavam cinqüenta e sete léguas.

No dia 16 de novembro, chegou ao rio Paraná. Subiu o rio Samambaia, até o porto em que, na viagem anterior, encontrara muitos índios caiuás, de nação guarani; aí encontrou o cacique Libânio, e outros muitos índios que, a pedido de Lopes, o cacique havia mandado chamar para receber presentes.

Libânio era de proporções atléticas, alto, reforçado e de uma fisionomia insinuante, respirando nas maneiras franqueza e magnanimidade, bem como em suas conversações muito tino e raciocínio; tinha vindo muito criança do lado do Paraguai, confundindo-se assim naquelas hordas, até que a sua valentia e prudência o elevaram àquele posto, com sete caciques sob suas ordens.

Depois de ser informado que Francisco Gonçalves Barbosa e seus companheiros haviam levado três índios de sua nação, Lopes visitou a aldeia, colocada entre as suas roças ou lavouras, que abundavam especialmente em milho, mandioca, abóboras, batatas, amendoins, jucutupé, carás, tingas, fumo, algodão, o que tudo era plantado em ordem.

\footnotetext{
${ }^{5} \mathrm{O}$ itinerário desta exploração foi publicado na Revista do Instituto Histórico e Geográfíco Brasileiro, 1850, v. 13, p. 315-335. Daí se extraíram as citações desta parte.
}

Albuquerque: revista de História, Campo Grande, MS, v. 1, n. 1, p. 207-226, jan./jun. 2009217 
No dia 20, na subida do rio Vacaria, seguindo, curioso, urubus que esvoaçavam, encontrou o Sertanejo os cadáveres de Francisco Gonçalves Barbosa, Paulo Rodrigues Soares e José Maria de Miranda, mutilados e já em estado de putrefação, assassinados pelos três índios. Retirou as cabeças dos infelizes assassinados, sepultou o resto de seus corpos, colocando-lhes em cima uma cruz.

No dia 6 de dezembro chegou à casa do falecido Barbosa, a cuja desventurada viúva deu a fatal nova da morte de seu marido e, no dia seguinte, à casa de Inácio Gonçalves Barbosa. A 2 de janeiro de 1849, partiu para Miranda, chegando no dia 6, onde requereu ato de corpo de delito nas cabeças dos infelizes assassinados, depois do que tiveram decente enterro com um acompanhamento o mais solene que era possivel fazer-se em tal lugar. No dia 12 voltou à Vacaria, parando na fazenda da Forquilha; no dia 20 chegou à fazenda de Antônio Gonçalves Barbosa.

No dia 12 de fevereiro começou a explorar os rios que da serra de Maracaju vertem ao Paraná, especialmente o Brilhante, o Santa Maria e o Dourados; após, desceu para a região entre os rios Amambaí-Guaçu ${ }^{6}$, Escopil ${ }^{7} \mathrm{e}$ Iguatemi, desistindo pela dificuldade de trânsito e mantimentos, depois de ter caminhado muitas léguas, em diversos ramos, até achar uma antiqüissima estrada de carretas, que entrava numa mata para as cabeceiras do Iguatemi em direção da serra de Maracaju, concluindo ser a estrada que da Redenção de Santo Inácio e Vila Rica seguia para Curuguaty.

Depois de atravessar algumas vertentes com águas para os rios Escopil e Iguatemi até a serra de Maracaju e encontrar águas do rio Apa, procurou as cabeceiras do rio Miranda e o sitio onde demorou a cidade de Xerez abandonada em 1648, não encontrando qualquer vestígio que lhe desse segurança para afirmar foi aqui.

Após, examinou o rio Miranda, concluindo ser dificílima a navegação até a foz do Nioaque, explorado no trajeto para o presídio, aonde chegou em 15 de março, gastando na tarefa trinta e dois dias de contínuas marchas e contramarchas. No dia 31 foi à fazenda da Forquilha, subindo o Miranda dezesseis léguas.

\footnotetext{
${ }^{6}$ Havia dois rios com o nome de Amambaí ou Samambaia (no guarani, Amambaí significa samambaia). O atual Amambaí era o Guaçu (ou Samambaí-Guaçu). O outro era o atual Samambaia.

${ }^{7} \mathrm{O}$ Escopil era o atual rio Jagüi, afluente, pela esquerda, do rio Iguatemi.
} 
No dia 8 de abril verificou o lugar do embarque e desembarque no rio Nioaque, em um ponto onde se lhe ajunta um arroio que denominou de Urumbeva, e ali fincou dois padrões de cerne de piúva, um na barranca do rio, outro no campo, gravando neles 1849 e B. de A. (Barão de Antonina).

No relatório está: da fazenda da Forquilha ao mencionado lugar marcado para o desembarque haverá doze léguas e para que fique a navegação franca em todo o tempo é preciso desobstruir algumas passagens.

Deixando aquele aprazivel lugar com proporções para uma povoação colocada na forqueta de Nioaque com Urumbeva, dirigiu-se ao rio Brilhante, atravessando a serra de Maracaju, anotando: nesta coxilha que faz divisa das águas dos dous gigantes Paraná e Paraguai, passa o trilho dos índios mirandeiros, que de tempo a tempo vão fazer suas correrias contra os pacificos caiuás; para concluir: seria muito louvável que por intermédio de V. Ex. ${ }^{a}$ soubesse o governo de $S$. Majestade Imperial as malversações e hostilidades que por vezes têm praticado os índios domesticados de Miranda, indo à caça dos Caiuás que habitam a margem direita de Ivinhema até a esquerda de Escopil e Iguatemi, com o único fim de fazer prisioneiros os pequenos e algumas mulheres, em cujas ocasiões o estrago e a morte se derrama nos bosques que servem de miserável abrigo a estes infelizes, dignos de melhor sorte e da proteção do governo, a quem não podem chegar suas débeis vozes.

Depois localizou Lopes um lugar azado para desembarque dos objetos que viessem da província de São Paulo, na forquilha do Brilhante com um ribeirão grande a que deu o nome de Santo Antônio, observando que aquele sítio (que chamou de São José do Monte Alegre), na barra daquele ribeirão, era o mais apropriado possível para se formar uma povoação, e que nas cabeceiras do varadouro (de oito a nove léguas) podiam formar-se duas colônias.

No dia 29 de julho, desceu o Brilhante, até chegar, no dia 5 de agosto, ao arroio das Sete Voltas, no dia 7 ao rio de Santa Maria, no dia 11 à foz do Dourados, observando que da foz do Santa Maria à do Dourados haveria por causa das voltas do rio quatorze léguas, e por terra oito. No dia 12 , com cinco léguas de navegação, chegou à foz do Vacaria. No dia 17 chegava ao porto dos caiuás, doze léguas adiante, onde acampou, fazendo contato bastante amistoso com aqueles índios, com danças e banquete. Com as necessárias precauções, conseguiu que o cacique lhe entregasse dois dos três índios que haviam assassinado Francisco Gon-

Albuquerque: revista de História, Campo Grande, MS, v. 1, n. 1, p. 207-226, jan./jun. 2009219 
çalves Barbosa e companheiros. Eram Mani (Mariano), sobrinho do cacique, e Taringoá (Estêvão), repassados ao comandante da escolta, furriel Antônio Dias Lemos, que dali os levou para seu destino até o forte de Miranda; o terceiro, chamado Sandu, descera o rio na canoa roubada (das vítimas), com a família.

Depois de três dias de viagem arranchou num bracinho do Paraná, que deságua no Ivinhema, de onde mandou uma diligência com o fim de capturar o terceiro assassino (voltaria sem encontrá-lo) e ele explorou, no espaço de dez a doze léguas, o braço direito do Ivinhema, vendo não ser possível tal caminho por terra.

No dia 31 atravessou o rio Paraná, e entrou no Paranapanema, para, no dia 15 de agosto, atingir o ribeirão das Congonhas, onde desembarcou; com mais dez léguas, chegou, no dia 3 de setembro, à fazenda da Fortaleza, encerrando seu giro.

A expedição de Lopes conseguiu o intento: a descoberta do varadouro ligando as bacias dos rios Brilhante e Nioaque, estabelecendo a ligação entre as terras paranaenses e o baixo Paraguai, como pretendia o barão de Antonina.

\subsection{AS TERRAS DO BAREO}

As duas expedições do Sertanejo no sul de Mato Grosso tinham segundas intenções. Sabia o barão de Antonina (João da Silva Machado, 1782-1875), senador, figura de destaque no Paraná, que seria promulgada uma lei facultando a todos os posseiros o direito de requerer, como própria, a terra de domínio público, sob ocupação, qualquer que fosse sua extensão. Ambicionando terras no sul de Mato Grosso, contratou os serviços de Lopes.

O sertanista, em suas explorações, ajudado por Luís Pedroso Duarte, de Miranda (que preparava os papéis), fez negócios, simulou outros (todos com defeitos essenciais), forjou escrituras, fazendo delas um simulacro de registro, perante o vigário da freguesia de Miranda, de tal forma que, no retorno, já havia adquirido para o barão as seguintes áreas ${ }^{8}$ a a primeira, em águas do rio

\footnotetext{
${ }^{8}$ Sobre as terras do barão e posterior questão jurídica, ver, de Astolfo Vieira de Resende. O Estado de Matto-Grosso e as suppostas terras do barão de Antonina. Rio de Janeiro, 1924, p. 12 e 53-95. Registre-se a valiosa colaboração, na obra, de Mário Monteiro de Almeida, então consultor jurídico de Mato Grosso.
} 
Dourados, de Inácio Gonçalves Barbosa (que nunca teve posses naquela região); a segunda, na margem direita do rio Dourados, de Manuel Vitorino (possível empregado de Antônio Gonçalves Barbosa); a terceira, nas cabeceiras dos rios Apa e Miranda, de Gabriel Francisco Lopes; a quarta, em continuidade à precedente, de José Carlos Botelho; a quinta, em águas do Iguatemi e Amambaí, de Antônio Cândido de Oliveira; a sexta, em águas do rio Apa, de Manuel Pereira da Rosa; a sétima, em águas dos rios Apa e Cruzes, de Jacinto Antônio Ferreira; a oitava, em águas do rio Pedra de Cal, de João José Pereira; a nona, em águas dos rios Santa Maria e São Domingos, de Antônio Gonçalves Barbosa.

Em 1906 João Abbott comprou do espólio do barão de Antonina as nove áreas, que vendeu em 1921, com o compromisso de os compradores pagarem um débito hipotecário que ele assumira. Em 1922, o espólio executou, na justiça, a hipoteca e no mesmo ano aquelas áreas eram penhoradas. Em 1923, Mato Grosso embargou a execução, alegando que aquelas terras eram devolutas. A questão

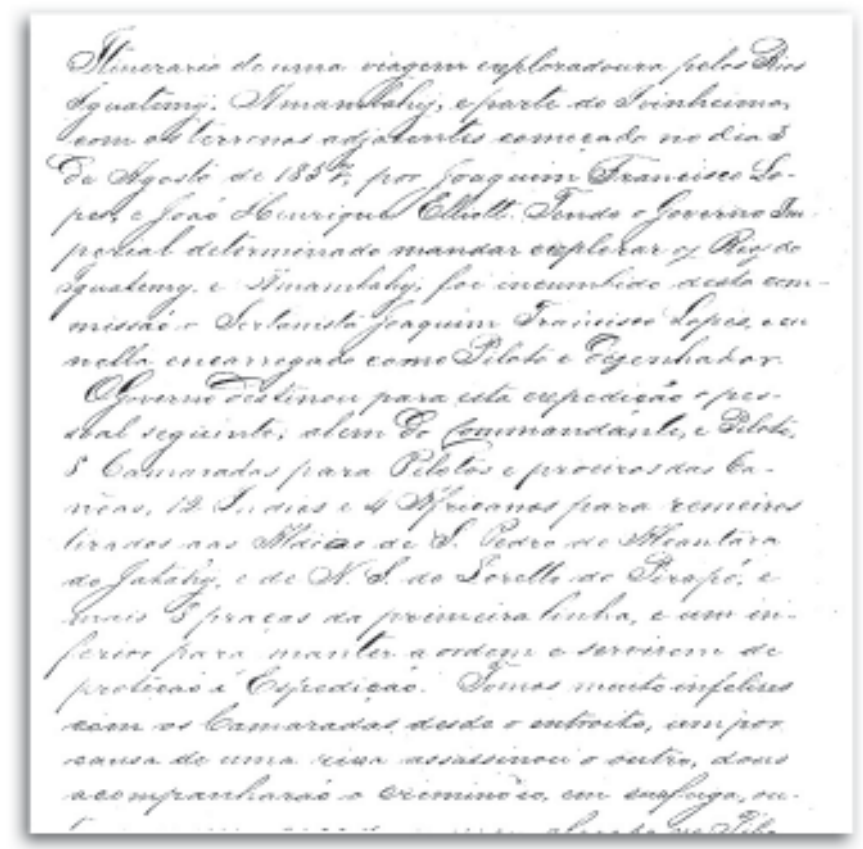

Início do original da quarta derrota: Itinerário de uma viagem exploradoura pelos Rios Iguatemy, Amambahy, e parte do Ivinheima, com os terrenos adjacentes começado no dia 3 de Agosto de 1857, por Joaquim Francisco Lopes e João Henrique Elliott. 
foi resolvida pelo Supremo Tribunal Federal em 1931. O espólio só teve os direitos reconhecidos sobre a fazenda Sete Voltas, instalada e mantida por um filho do barão, de nome Pedro Nolasco.

\section{QUARTA DERROTA (Paraná - Iguatemi)}

As informações desta terceira exploração9 são indispensáveis para entender como se encontrava a região entre os rios Ivinhema e Iguatemi na metade do século 19.

Por ordem do governo imperial, Joaquim Francisco Lopes explorou os rios Iguatemi e Amambaí bem como parte do Ivinhema, com os terrenos adjacentes, acompanhado por João Henrique Elliott, piloto e desenhador.

No dia 3 de agosto de 1857 a comitiva principiou a viagem no porto do Jataí. No dia 14 entrou no rio Paraná. Descendo-o, passou pela barra do Samambaia e entrou no Ivinhema, onde havia uma aldeia de índios (o atual porto Caiuá); adiante, passou pelo rio Nanaí (atual Laranjaí - rio das laranjas), onde também havia aldeamento de índios caiuás; no dia 17, retornando, entrou no Paraná. Consta, nesta parte do relatório, minuciosa descrição do rio Ivinhema, chamado pelos índios de Iragui (rio de muitas ondas). A 18 entrou na barra do Amambaí ou Samambaí-guaçu; a 20, começaram a aparecer muitos vestígios de índios e mais mato alto. No dia seguinte descobriu um trilho bem freqüentado perto do pouso, que conduzia até a aldeia do cacique Paí-Guaçu. No dia 23 os índios começaram a aparecer. Lopes distribuiu entre eles machados, facões, fouces, fazendas. Continuando a exploração, encontrou mais vestígios de índios em ambas as margens, tanto que, no dia 29, se apresentaram índios do cacique Paí-Mirim, poucos, pois os demais andavam à caça para o lado do Campo Grande, distante três dias de viagem.

No dia 30, fez pouso na barra de um lindo córrego, que chamou de ribeirão da Sardinha. No dia seguinte, encontrou outro belo ribeirão, a que deu o nome de Areia

${ }^{9} \mathrm{O}$ itinerário desta exploração, manuscrito, encontra-se arquivado no Instituto Histórico e Geográfico Brasileiro, lata 92, pasta 10 (documentos, f. 22-44). 
Branca. Em 1. ${ }^{\circ}$ setembro, subindo o rio Amambaí, cada vez mais sinuoso, encontrou canoa e porto de índios muito freqüentado, no lado direito, onde fez pouso. Constatou que aqueles índios caiuás se achavam espalhados pelos matos em pequenas hordas de dez a trinta famílias, tendo cada aldeamento somente um rancho grande onde todos se acomodavam; e tinham relações amigáveis entre si e com os paraguaios.

No dia 3 de setembro, subindo o rio, encontrou mais índios e, no dia seguinte, outros, cujas roças e rancho visitou. Relata: Era um grande rancho que tinha duzentos e noventa e sete palmos de cumprimento, setenta e dois de largura e trinta de alto; no interior duas carreiras de esteios e que distantes sustentavam as travessas onde se encostavam os caibros, os quais serviam para suspender as suas redes de dormir, de maneira que se pode saber o número das famílias contando estes esteios. Notando que só o chefe e os homens dormiam na rede (as mulheres, no chão), conclui: este rancho tinha lugar para vinte e quatro famílias. Soube que o terreno entre o Ivinhema e o Iguatemi, e mesmo além deste último, estava povoado de caiuás que se comunicavam entre si por picadas, e que tinham trilho desde o Paraná até os campos da Vacaria.

Subindo ainda o rio Amambaí, chegou ao Ituguaçu (salto grande) - até aí o rio era navegável (trinta léguas desde a foz) - e, duas léguas acima, ao Itupecapó (salto do pula-peixe). No dia 5, começou a descer o rio Amambaí, para, no dia 9, chegar ao Paraná, fazendo pouso, duas léguas abaixo, na barra do Maracaí. Logo abaixo começa a ilha Grande ou das Sete Quedas.

Nesta altura do relatório, há descrição pormenorizada do rio Amambaí - rio da samambaia, por causa da muita samambaia que tem nas suas margens. Observa: Nas vizinhanças deste rio habitam muitas pequenas hordas de indios caiuás, gente social, de boa indole e bons princípios de agricultura; será fácil ajuntá-los em uma ou duas grandes; o rio Amambai oferece muitas vantagens para este fim, anotando, por fim, que os índios têm muita variedade de plantas, como milho, feijão, mandioca, amendoim, cana, algodão e bananeiras. Do rio Maracaí está anotado que é navegável por canoas oito a dez léguas e que, perto das cabeceiras, existiam algumas aldeias de caiuás.

No dia 11, seguiu viagem, pousando numa pequena ilha para calafetar uma canoa e por esta causa tomou o nome de ilha do Calafetar. No dia 12, 
depois da foz do Pirajuí (rio dos dourados), fez pouso na barra do rio Mutum-i (rio dos mutuns), de onde se ouvia distintamente o barulho do salto das Sete Quedas. No dia 13, depois de observar que o Paraná é semeado de ilhas, informa: entramos no Iguatemi, com trinta e três braças e meia de largura com quatorze palmos de fundo. No dia 14, encontrou, no lado sul, muitas árvores de congonha de qualidade superior, apanhando alguma para fazer erva-mate.

No dia 15, encontrou um porto de índios, do capitão Matias, que morava duas léguas retirado daí. Adiante, encontrou uma canoa e porto dos índios no lado meridional. Naquela altura do Iguatemi, deu a um ribeirão o nome de Sucuri e a outro, pouco acima, de Claro. Por original, está anotado um incidente: matouse ai um sucuri com vinte e nove palmos de comprimento; o réptil estava com a barriga cheia, abrimos para ver o que continha, era outro sucuri com dezesseis palmos de comprimento. Que vivacidade!

Acima, deu o nome de Pé de Areia a um córrego e de Verde a um ribeirão. Encontrou aí um lugar estreito que serve de passagem aos índios, a qual eles chamam Itapó (pedra de pular). No dia 19, encontrou índios do capitão Perón e alcançou o rio Escopil, chamado pelos índios Iguai (rio Claro), afluente, pela esquerda, do Iguatemi. O capitão contou-lhe que tinha muitas aldeias de sua gente no lado meridional do Iguatemi e que todos moravam em matos de cultura; conservava relações com os paraguaios, ajudando-os nos ervais e recebendo em troca de seus serviços machados ingleses, machetões, facas e facões ingleses e pano de algodãozinho.

Nos dias 20 a 23 explorou o rio Escopil, onde o maior inimigo que se encontra ai é o terrivel sucuri. Examinada a topografia, anotou: por esta mesma coxilha pode ir-se aos Dourados no passo do Iguaicuru. Acrescente-se que diariamente o Sertanejo encontrava índios, como no dia 24, os dos capitães Cangaçu (cabeça grande) e Ramos.

No dia 26, queimou campinas de sapezais, atingindo bastante erva-mate, que deu lugar a fazerem uma porção. A 27 passou pelo pequeno rio Iputã. A 28, começou a enfrentar as quatorze cachoeiras do Iguatemi; às três horas da tarde viram os expedicionários um porto de índios muito freqüentado e outros vestígios que não eram de índios em pique aberto cortado rente os ramos do chão e o rasto de dois cavalos, onde tinha uma canoa com dois remos feitos 
por oficiais de carapina. (....) Achou-se também o lugar de dois fogões, com uma trempe de gancho à maneira dos tropeiros paulistas, e outra à moda dos curitibanos, que é de duas forquilhas e uma travessa, e ossos de gado. Os vestígios eram, como soube, de desertores de uma guarda paraguaia, distante dali seis a oito léguas, provavelmente dos ervais da serra de Maracaju.

No dia 4 de outubro, passou pela barra do pequeno rio Bogas (chamado pelos indios Iguaterai-Mirim). No dia seguinte, procurou e encontrou o lugar do forte abandonado de N. S. dos Prazeres do Iguatemi, demolido pelos espanhóis em 1777, duas léguas acima do Bogas.

No dia 6 encontrou os primeiros vestígios do forte: uma vala ou poço quase entupido que embicava em um brejo, seguindo por este as valas, continuamos sempre formando ângulos, alguns bem salientes, alguns destes ângulos tinham trinta passos de comprimento, outros com mais de duzentos; depois de passar este entramos num que tinha pelo menos cinqüenta palmos de largura com vinte e cinco a trinta de fundo; tem outros paralelos de distância de vinte passos e do mesmo tamanho, tão bem conservados que alguns lugares ainda se distinguem os sinais de enxadas; neste lugar parece-me que estava o portão. Do forte, partia um caminho para o rio e a serra de Amambaí, anotando que daí até os primeiros moradores vacarianos havia de trinta a trinta e cinco léguas, e até o primeiro forte paraguaio (a Bela Vista) do lado meridional do Apa a mesma distância pouco mais ou menos. Por fim, registra que o local dos Prazeres, muito bem localizado, é muito aprazível avistando-se o curso do rio Iguatemi, bem longe, serpeando por matos, especialmente pelo meridional onde até alcança a vista tudo é mato.

Argumentando que todo o terreno dai por diante já havia sido explorado por ele, em derrota anterior, deu por encerrada a exploração, iniciando o retorno.

No dia 7 encontrou um índio que se intitulava capitão Pedro Ivo; era um velhinho de seus sessenta anos, trazia uma farda paraguaia de alferes, e uma qualidade de barretina azul com divisa encarnada, muito jovial, oriundo dos ervais do Paraguai, reclamando que o serviço era muito e o dinheiro nada. No dia 10, já abaixo da foz do Escopil, fez erva-mate por haver ai muita. Nesta altura, consta no relatório a descrição do rio Iguatemi e seus afluentes, principalmente o Escopil. No dia 25 de outubro fez pouso na baía da ilha da Meia Lua. Nesta parte do

Albuquerque: revista de História, Campo Grande, MS, v. 1, n. 1, p. 207-226, jan./jun. 2009225 
relatório está a descrição de parte do rio Paraná, destacando que a corrente deste rio é pouco apressada mas com o vento forte levanta ondas como oceano. No dia 11 de novembro, entrava a comitiva no rio Tibagi para, no dia 14, desembarcar no Jataí. 